\title{
Islam and Economic Growth
}

\author{
Hamdi Khalfaoui ${ }^{1}$ \\ ${ }^{1}$ PS2D laboratory, Faculty of Economics and Management, University of Tunis El Manar, Tunisia \\ Correspondence : Hamdi Khalfaoui, 110 cité balaoui, route haffouz, Kairouan 3100, Tunisia
}

Received: August 10, 2015

Accepted: August 25, 2015

Available online: September 18, 2015

doi:10.11114/ijsss.v3i6.1019

URL: http://dx.doi.org/10.11114/ijsss.v3i6.1019

\begin{abstract}
Nowadays, Muslim countries remain among the least developed countries on all levels, although they are rich in natural resources. Islam, as the common religion of these countries, can be the cause of their underdevelopment? In this context, our paper aims to investigate the impact of Islam, as a proportion of the Muslim population, on economic growth on the one hand, and to seek the factors that may influence this relationship on the other hand. Our empirical study using panel data on a sample of twenty Muslim countries over the period (1990-2014), show that Islam does not promote economic growth. Its effect is lower and negative in the way that Muslim countries have high rates of illiteracy and unemployment.
\end{abstract}

Keywords: Islam, illiteracy, unemployment, economic developments, panel data

\section{Introduction}

The Islamic world, which represents about $20 \%$ of the population worldwide (more than a billion) is more than ever exposed to incommensurate economic and social changes, which scale has been intensified by the globalization phenomenon.

Indeed, since 1987 many geopolitical events (skyrocketing oil prices, the debt crisis, the Golf war invasion of Iraq, terrorism, etc.) propel the Arab-Muslim world in the heart of the concerns of analysts. Thus, the Muslim countries including the rich countries, namely the Petroleum Producers, have become case studies, observation and privileged analysis by researchers.

The debate on the correlation between Islam and economic development is still uncertain and unclear. The literature on the theoretical level is divided into two schools of thought. Some authors claim that Islam is negatively associated with economic growth. Others argue that it promote growth.

Empirical research on the determinants of economic growth in Muslim countries has often neglected the influence of Islam. It is in this context that this paper aims to explore the relationship between Islam and economic growth on the one hand and the factors that may influence them on the other hand.

Our empirical study, conducted on a sample of twenty panel countries over the period 1990-2014, show, in a first regression, that Islam is negatively correlated with economic growth. In the second and third regression, we find that the effect of Islam is lower and negative that Muslim countries have high rates of illiteracy and unemployment.

The structure of this paper is as follows: the first section reviews the main work on the relation between Islam and economic development. The second section presents the research methodology including the model. The third section presents and discusses the results found, followed by a conclusion in the fourth section.

\section{Literature Review}

Weber (1968) was the first who raised the controversy between Islam and capitalism, precisely on the non extension of capitalist industrialization in the Middle East. McClelland (1961) states that Islam is an obstacle to growth and this appears especially in countries that have built their economic and social systems on the basis of Islamic law. This argument is based on historical and descriptive facts. Likewise, Rodinson (1967) and Bryan (1978) argue that the economic decline resulting from the character of both capitalist and conservative Islamic religion from the Muslim state itself which is static and despotic. Other authors such as Guiso, Sapiegranza and Zingales (2003) argue that Muslims are "anti-market"; since they believe that Islam is negatively associated with attitudes favorable to growth. The authors criticize the foundations of Islamic laws that derive their legitimacy first of all from the Koran but also from the "Sharia, 
Ijmaa or El Qyas". (Note 1)

According to Islam, the distribution of the wealth responds to the belief of Muslims in the unit principles (Tawheed) which sets out the oneness of God and equality among men. In economic terms this means mutual aid. The resources in terms of capital should be shared among members of society. The rich must help the poor.

The most controversial rule is that the zero interest rate. Thus the lack of interest is a crucial feature of the Islamic financial system. In this respect, Pryor (1985) addresses a major criticism in the Islamic economic system. He says that this system leads to lower savings and financial intermediation disadvantage and consequently it is not able to support economic growth. (Note 2)

Several near-unanimous beliefs claim that Muslim countries are still suffering from economic and social recession. This position is reinforced by an inventory which shows a growth paradox that characterizes some Arab and Muslim countries. Indeed, some Arab and Muslim countries are full of resources but seem to be caught in a kind of "poverty trap" where they are struggling to emerge.

Some authors (Said (1978), Kuran (1998) and Nafissi (1998)) attribute poverty in Muslim countries to Islam itself insofar as it is a religion that preaches fatalism and is unfavorable to growth. Moreover, for these authors, Islam introduced a form of relationship with the company contrary to the requirements of the open and extroverted modern world. Islam is a set of intimate union with practical values and principles dictated by both the Koran and "Sharia". It can influence the institutional choices that impact directly the entrepreneurial and investor behavior and the economic growth.

According to the UNDP report (2002), Muslims are classified as underdeveloped countries, characterized by low GDP, high rates of poverty, a significant level of illiteracy, technical and technological backwardness and inadequate institutional framework. With the exception of oil-producing countries, which are not necessarily rich, Muslim countries are generally suffering from a chronic budget deficit, an average life expectancy and low purchasing power.

The causes of this decline may be explained by relatively economic factors (low growth, low real rate of investment, inefficient allocation of resources), geographic (harsh climate, mountainous regions), political (totalitarian, dictatorship etc.), cultural (fanaticism, obscurantism, limited role of women) institutional and legal (corruption, injustice, bureaucracy, bad governance, etc.)

Max Weber in his critical analysis of Muslim political and legal institutions as opposed to those of the Western world considers the "prebendary feudalism" and "arbitrary bureaucratic patrimonialism" features of Abbasid, Mamelukes and Othmanes dynastieshave prevented the development of rational legal structures.

With the exception of some Muslim countries (Iran, Malaysia, Pakistan, and Turkey) who managed to secure relatively fairly sustainable growth levels, the rest of the Muslim world is still stuck in an imbalanced situation, thus constituting a poverty trap and higher unemployment.

Authors such as Kuran (2004) and Fachini (2007), explain underdevelopment of Muslim countries by government models of the Arab-Muslim countries. Fachini says that "democracy is the emblem of the West ... Islam is a religion in its frozen timelessness and inherently incompatible with political modernity and democracy."

The Muslim world is uncertain and the supporters of the thesis that Islam is associated with underdevelopment, base their thought on a certain number of economic, political and cultural facts.

The main handicaps faced by Arab and Muslim countries come from the socio-economic behaviors that hinder development and economic growth.

Therefore, even the rich countries (but no less underdeveloped), such as the oil producing countries do not seem to enjoy their pensions. According to the President of the Pan-Arab Economic Council, oil prices explod revenues of some Arab countries about $33 \%$ but the bulk of oil revenues are invested in real estate sector and weapons rather than in creating sectors jobs.

Some analysts evoke of the "oil curse" since the oil rent annihilated production and industry. Thus, for example in Saudi Arabia, $70 \%$ of the state budget is based on oil revenues. Industry and services are focused on the extraction and processing of oil. Agriculture accounts only 5\% of GDP.

This situation is not exclusive to Saudi Arabia, but to other oil-producing countries suffering from a weak economic system that dependent on oil prices and quotas negotiated in OPEC.

The main blocking for these countries does not due to a lack of resources, nor to macroeconomic imbalances, that seem to be more or less controlled. It is result from inconvenient choice of economic policy, resource allocation and marginalized by inappropriate legal and institutional framework.

Conversely, some authors (Gardet 1970, Sauvaget 1984, Barro and Mccleary 2003 and Haenni 2005) show that Islam as a set of moral and behavioral values is positively associated with economic growth. They base their argument on 
historical facts going back to the glorious eras of the world Muslims who have long dominated the European world, since the middle ages until the 18th century. Gardet (1970) and Sauvaget (1984) date back to century's conqueror of the Umayyad (661-758) who's the chief, named "Kalifa" led the Muslim empire to its greatest territorial extension. This reign has implemented administrative, legal, business and cultural systems that have propelled the Muslim world in its heyday.They also cite the golden centuries of the Abbasid who occupied half a millennium (750-1258). During these eras of reign, Islam as a moral practice, social and economic in accordance with his principles religious could be a social cohesion and has helped to build a rich and developed society.

Closer in time, it is also important to highlight the success observed by Islamic finance worldwide. Islamic banks base their intermediation systems on strict religious principles seeking to replace the interest by other more flexible and less risky forms and instruments (Musharaka, Moudharaba, Ijar, Sokouk, etc.) are experiencing a runaway success.

A study by the International Monetary Fund (2005), Islamic finance is developing at a rapid and sustained. In 1960 there was only one bank and now more than 300 Islamic financial institutions exist in 75 countries worldwide. These banks are located at 60\% in the Middle East, 20\% in South Asia and 20\% in the rest of the world.

Islamic banks are experiencing a boom and an outstanding success. They show themselves effective in mobilizing deposits and recorded a very high market penetration rate. According to the IMF and the World Bank, their assets in 2013 exceeded two trillion dollars with an annual growth rate of $16 \%$.

Patrik (2005) shows that Islam obeys an economic logic and pro market: he said that "a new Islam with outward forms, a new religious setup ... That we call market Islam.... because of its affinity with the institutions of the economic field which will serve as a support and with the new corporate culture".

Moreover, the empirical exploration seems to be preferred by some authors to capture the impact of Islam on economic performance. This is to see if belonging to a certain culture acts positively the determinants of economic growth. The empirical results are often controversial and uncertain. They vary depending on the sample size, horizon, measuring indictor of Islam and regression methods used.

Kuran (1998) resulted to a negative and significant relationship between Islam and economic growth. His study is conducted in cross section for 132 countries. A best fit is obtained with the introduction, in a second regression, other independent variables. The relationship remains negative and significant, while indicating that the growing Muslim proportion in the population harms economic growth. On the contrary, Barro and Mccleary (2003) conclude that economic growth responds positively to the extent of religious beliefs, including those of hell and heaven, but negatively of church attendance. These results show that religious beliefs can influence individual traits that improve economic performance. Likewise, Noland (2007) compares the effect of Christianity, Islam, Buddhism, Hinduism and Judaism on economic growth given level of development. The author has conducted its analysis on 50 and 70 countries and within 3 multi-faith countries, it has shown that given level of economic development, Islam promote growth.

Fachini (2007) shows that the relationship between Islam and economic development is a difficult question and shares many authors of social sciences. It highlights the latest "it is important to distinguish between the moral and the causal relationship ... that Islam is or is not an obstacle to economic development, does not affect its ability to say good and bad ... Islam can be a factor of progress without moral cause of economic progress."

In reviewing this literature linking Islam to economic development, it appears that:

H1: the link between Islam and economic development is skeptical and uncertain. Its existence is often nuanced and controversial.

H2: socio-economic conditions of Muslim countries determine, to a large proportion, the nature of relationship between Islam and economic development.

\section{Method}

Empirical research on the determinants of economic growth has often neglected the influence of religion. Even the few studies dealing with the subject suggest that the link between religion and growth is still complex and uncertain.

\subsection{Proxy variables}

3.1.1 The dependent variable: economic growth. It is measured by real GDP per capita growth rate

3.1.2 The independent variables are divided between control variables and explanatory variables.

a. The control variables are:

- The stock of human capital (H.K), estimated by the average secondary school enrollment.

- The growth rate of the population (Population) 
- The trade openness of the economy (Trade), estimated by the volume of exports plus imports as a percentage of GDP.

- The rate of inflation (Inflation), measured by the general consumer price index.

b. The explanatory variable (Islam) is estimated by the Muslim proportion in each country (practicing and non-practicing Muslims). (Note 3)

\subsection{The sample selection}

Our sample is composed of twenty Muslim countries, distributed among fifteen Arab-Muslim countries (seven MENA countries, seven GOLF countries and Sudan) and five non-Arab Muslim countries. These countries are in different situations (level of real GDP per capita natural resources, size, unemployment rate, prominence of state, language, culture, etc.), gathered around Islam, as that important moral factor in social and economic life of Muslims. (Note 4)

\subsection{Model specification}

The consideration of individual data allows us to better understand the various factors that could explain growth. Certainly the econometrics of panel data seems to be the most appropriate way of research. Therefore, we use the annual panel data composed of a sample of 20 Muslim countries and extended over a period of 25 years from 1990 until 2014.

The model takes the following general form: $y_{i, t}=\alpha_{i}+\lambda_{i} V C_{i, t}+\beta_{i}$ Islam $_{i, t}+\varepsilon_{i, t}$

$$
\forall i \in[1,20], \forall t \in[1990,2014]
$$

This equation could be interpreted as part of a panel analysis in the following expanded form:

$$
Y_{i t}=\alpha_{i}+\sum_{j=1}^{j=M} \lambda_{i j} V C_{i j t}+\sum_{j=1}^{j=K} \beta_{i j} \text { Islam }_{i j t}+\varepsilon_{i t}
$$

Where, $\mathrm{Y}$ is the rate of economic growth, C.V are Control Variables and $\varepsilon_{\mathrm{it}}$ is the error term.

$$
\mathrm{E}\left(\varepsilon_{\mathrm{it} 1)}=0 ; \quad \mathrm{E}\left(\varepsilon_{\mathrm{it}}^{2}\right)=\sigma_{\varepsilon}^{2} \quad \text { et } \mathrm{E}\left(\varepsilon_{\mathrm{it}} \cdot \varepsilon_{\mathrm{js}}\right)=\sigma_{\mathrm{ts}}+\mathrm{s} \sigma_{\mathrm{ij}} \sigma^{2}\right.
$$

\subsubsection{Specification of individual effects tests}

The specification test of individual effects is whether we are entitled to assume a totally identical function for all countries. Otherwise the specificities of each country must be considered. The result of this test is a statistical Fisher. A degree of risk of $5 \%$ we accept the null hypothesis of equality of constants. It is not therefore necessary to introduce the individual effects. The most suitable estimator is the Generalized Least Squares (GLS). (Note 5)

\subsubsection{Tests of heteroscedasticity and autocorrelation}

To correct the problem of heteroscedasticity of residuals we use the Wald test. This test statistic follows Chi2(20). To a degree of risk of 5\%, we accept the null hypothesis of heteroscedasticity residues ( $\mathrm{P}$-value $<5 \%$ ). Then, we conduct the test of Breusch-Pagan to correct the problem of autocorrelation inter-individual, The resulting statistics of this test follows a Chi2(190). To a degree of risk of 5\%, we accept the null hypothesis of autocorrelation between individuals (P-value<5\%).

\subsection{Estimation Results}

The specification of the empirical model takes the following form:

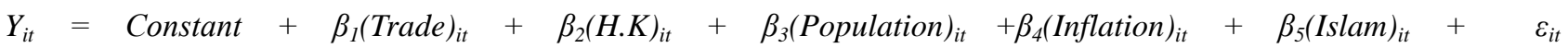
$\forall i \in[1,20], \forall t \in[1990,2014]$

The estimation results displayed in Table 1, show that all variables are significant.

Table 1. Estimation results of Model 1

\begin{tabular}{ll}
\hline VARIABLES & Model 1 \\
\hline Trade & $0.00603^{* * *}$ \\
& $(0.00251)$ \\
H.K & $0.0171^{* * *}$ \\
& $(0.00417)$ \\
Population & $-0.870^{* * *}$ \\
& $(0.0327)$ \\
Inflation & $-0.0151^{* * *}$ \\
& $(0.00362)$ \\
Islam & $-0.0320^{* * *}$ \\
& $(0.0102)$
\end{tabular}




\begin{tabular}{ll} 
Constant & $0.0610^{* * * *}$ \\
& $(0.00951)$ \\
Observations & 500 \\
Number of country__ & 20 \\
\hline
\end{tabular}

Standard errors in parentheses

$* * * \mathrm{p}<0.01, * * \mathrm{p}<0.05, * \mathrm{p}<0.1$

- Trade openness is positive and significant. This means that open economies could benefit from their comparative advantages and initiate therefore a higher growth rate.

- Human capital is positive and significant. This result implies that investment in education is a substantial guarantee for the development and for a long-term economic growth.

- The population is negative and significant. This implies that proliferation of population lessen economic growth.

- Inflation is negative and significant. The increase in the general price index has a harmful effect on economic growth.

- The variable linked to Islam is negative and statistically significant. This result which joins Pryor (1985), Kuran (1998, 2004), Guiso, Sapienza and Zingales (2003), implies that the growing Muslim proportion impedes economic growth. Thus, the decline of Muslim countries comes, in part, from Muslims themselves. The existence of inadequate legal and institutional framework and an unfavorable socio-economic environment, despite abundant natural and financial resources, explain the problem of underdevelopment in these countries.

\subsection{The impact of illiteracy and unemployment}

For a better fit of the previous model, we chained by the introduction of two new variables reflecting the impact of illiteracy and unemployment. Thus the specification of theoretical model takes the following form:

$$
\begin{gathered}
Y_{i t}=\alpha_{i}+\gamma_{i} V_{i t}+\beta_{i} \text { Islam }_{i t}+\delta_{i} \text { Illeteracy }_{i t}+\lambda_{i} \text { Unemployment }_{i t}+\varepsilon_{i t} \\
\forall i \in[1,20], \forall t \in[1990,2014], \forall j \in[1,2]
\end{gathered}
$$

-The illiteracy rate (Illeteracy) is measured by the share of the population unable to read and write with understanding a text.

- The unemployment rate (Unemployment) is measured by the share of the labor force without work but available for and seeking employment.

Equation (2) is the basis for the estimate of the relationship between Islam and economic development with the presence of illiteracy and unemployment rates.

Empirically, the null hypothesis of equality of the constants is accepted. It is not therefore necessary to introduce individual effects in the model. The chosen estimator is the Generalized Least Squares. (Note 6)

For heteroscedasticity of residuals and autocorrelation between individuals, null hypotheses Wald test and Breusch-Pagan test are respectively accepted. (Note 7)

Table 2 presents the results of the following theoretical model:

$Y_{i t}=$ Constant $+\beta_{I}(\text { Trade })_{i t}+\beta_{2}(\text { K.H })_{i t}+\beta_{3}(\text { Population })_{i t}+\beta_{4}(\text { Inflation })_{i t}+\beta_{5}(\text { Islam })_{i t}+\beta_{6}(\text { Illiteracy })_{i t}+$ $\beta_{7}\left(\right.$ Unemployment $_{i t}+\quad$ eit $; \forall i \in[1,20], \forall t \in[1990,2014]$

Results found, according to the second regression, shows that all variables are statistically significant.

Table 2. Results estimation of model 2

\begin{tabular}{ll}
\hline VARIABLES & GLS \\
\hline Trade & $0.00709^{* * *}$ \\
& $(0.00234)$ \\
H.K & $0.0284 * * *$ \\
& $(0.00389)$ \\
Population & $-0.909 * * *$ \\
& $(0.0319)$ \\
Inflation & $-0.0136^{* * *}$ \\
& $(0.00301)$ \\
Islam & $-0.0248^{* * *}$ \\
& $(0.00918)$
\end{tabular}




\begin{tabular}{ll} 
Illeteracy & $-0.0149 * *$ \\
& $(0.00644)$ \\
Unemployment & $-0.0593 * * *$ \\
& $(0.0102)$ \\
Constant & $0.0622^{* * *}$ \\
& $(0.00819)$ \\
Observations & 500 \\
Number of country & 20 \\
\hline
\end{tabular}

Standard errors in parentheses

$* * * \mathrm{p}<0.01, * * \mathrm{p}<0.05, * \mathrm{p}<0.1$

- The Muslim share of the population (Islam) remains negative and significant

- The rate of illiteracy and unemployment rates seem negative and highly significant. This result, which joins those of Said (1978), Kuran (1998) and Nafissi (1998), implies a high rate of illiteracy and unemployment in Muslim countries is a major social handicap and consequently hinders economic growth.

Are the two social conditions anchored to Islam? Das Their negative effects on growth, will be amplified if the Muslim proportion increases? To answer these questions, explore a third regression, taking into account the intensity of Islam under the conditions of illiteracy and unemployment.

3.6 The impact of Islam under illiteracy and unemployment

To better understand the nature of the relationship between economic growth and Islam, we proceed with the introduction in the initial model of two interactive variables reflecting the impact of Islam under the terms of illiteracy and unemployment. Thus the theoretical model is written as follows:

$$
Y_{i t}=\alpha_{i}+\beta_{i} \text { Islam }_{i t}+\lambda_{i} \text { Islam_illeteracy }_{i t}+\delta_{i} \text { Islam_unemployment }_{i t}+\gamma_{i} V C_{i t}+\varepsilon_{i t}
$$

$$
\forall i \in[1,20], \forall t \in[1990,2014], \forall j \in[1,2]
$$

With, "Islam_illeteracy"and "Islam_unemployment" are interactive variables reflecting relationship between Islam and economic growth under illiteracy and unemployment. If, for example, the interaction variable (Islam_llleteracy) is negative and significant, it implies that the effect of Islam on economic growth is particularly weak and negative that Muslim countries have a high rate of illiteracy.

Empirically, in the same sense as the first and the second regression, the null hypothesis of equality of the constants is accepted. It is not therefore necessary to introduce the individual effects in the model. The suitable estimator is the Generalized Least Squares (GLS). For heteroscedasticity of residuals and autocorrelation inter-individuals, null hypotheses of Wald and Breusch-Pagan are accepted. (Note 8)

The model specification is written as follows:

$Y_{i t}=$ Constant $+\beta_{1}(\text { Trade })_{i t}+\beta_{2}(\text { K.H })_{i t}+\beta_{3}(\text { Population })_{i t}+\beta_{4}(\text { Inflation })_{i t}+\beta_{5}(\text { Islam })_{i t}+\beta_{6}(\text { Islam_illeteracy })_{i t}$ $+\beta_{7}(\text { Islam_unemployment })_{i t}+$ sit $\quad ; \forall i \in[1,20], \forall t \in[1990,2014]$

Results found according to Table 3 show that all variables are statistically significant.

Table 3. Estimates results of Model 3

\begin{tabular}{ll}
\hline VARIABLES & GLS \\
\hline Trade & $0.00586 * * *$ \\
& $(0.00198)$ \\
H.K & $0.0301 * * *$ \\
& $(0.00331)$ \\
Population & $-0.885 * * *$ \\
& $(0.0276)$ \\
Inflation & $-0.0189 * * *$ \\
& $(0.00282)$ \\
Islam & $-0.0168 * *$
\end{tabular}




$\begin{array}{ll}\text { Islam_illeteracy } & -0.0219^{* * * *} \\ & (0.00577) \\ \text { Islam_unemployment } & -0.0508^{* * *} \\ & (0.00817) \\ \text { Constant } & 0.0553^{* * *} \\ & (0.00661) \\ \text { Observations } & 500 \\ \text { Number of country_ } & 20\end{array}$

Standard errors in parentheses

$* * * \mathrm{p}<0.01, * * \mathrm{p}<0.05, * \mathrm{p}<0.1$

The variable related to Islam is negative and significant, confirming its negative effect on economic growth. Similarly, interactive variables (Islam_illeteracy and Islam_unemployment) are negative and highly significant. Thus, the effect of Islam on economic growth is particularly weak and negative that Muslim countries have a high rate of illiteracy and unemployment.

This result joins those of Fachini (2007), Kuran (2004) and Laporta and AL (1997), which explain the negative impact of religions on development, by other aspects of government corruption, failing judicial systems, miserable conditions social and increased bureaucracy.

To sum up, Poverty and poor birth control in Muslim countries in Africa and Asia; the low enrollment and gender inequality in Muslim countries GOLF; terrorism, unemployment and inappropriate choice of economic policies in the Muslim countries of MENA; are the main handicaps of these countries, namely the Arab-Muslim countries that seem to be stuck in a poverty trap from which they are struggling to emerge.

\section{Conclusion}

The relationship between Islam and economic development is the subject of a controversial debate among economists, sociologists, historians and scholars of Islam. Supporters of Islam base their argument on historical facts going back to the glorious centuries of Islamic countries, where Muslims have been on the forefront of the economic and scientific scene. While opponents to Islam, defend their positions based on socio-economic facts. The explanations that they have advanced show that Muslim countries are being downgraded and suffer from prolonged under development. For them Islam is frozen in timelessness and incompatible with modernity and development.

It is through the empirical exploration that we have chosen to position itself to the issue of the impact of Islam on economic growth, without bias and without hasty and subjective assertions.

It is through the empirical exploration that we chose to explore the correlation between Islam and economic growth and to "contextualize" the issues without bias and without hasty and subjective assertions.

Our first hypothesis of absence the relationship between Islam and economic development is rejected. Indeed, the results found in all three regressions, leading to a negative relationship. This verdict means that the higher Muslim proportion, the less will be the economic development

While the second hypothesis, postulating that the effect of Islam on growth is closely linked to special social conditions is validated. Indeed in the second and third regression we concluded that in Muslim countries, the negative effect of Islam on economic growth increase where illiteracy and unemployment are widely introduced.

Certainly, Islam like other religions is instigators of economic development. They promote the work, knowledge and enrichment as it shown in verse $\mathrm{n}^{\circ} 105$ of Surat Et-Tawbah of Koran, And say, "Do, because God will see your deeds, as His Messenger and the believers. You will be returned to the Knower of the unseen and the witnessed, and He will inform you of what you used to do." and in verse $\mathrm{n}^{\circ} 11$ of Surat Al-Mujādila,"God will raise those who have believed among you and those who were given knowledge, by degrees. And God is acquainted with what you do".

The example of the golden centuries of Muslims lived mainly in the Ottoman and Abbasid empires, argues that the Islam could be a social cohesion and has helped to build a rich and developed society.

Nevertheless, we can't deny that underdevelopment of Muslim countries, is partly caused by beliefs and values rooted in Islam itself. (Note 9)

\section{References}

Barro, R., \& Mc.Cleary, R. (2003). Religion and Economic Growth across Countries. American Sociological Review., 
68(5), 760-781.

Bryan, S. T. (1978). Orientalism, Islam and Capitalism. Social Compass, 25(3-4), 371-394. http://dx.doi/10.1177/003776867802500305

Fachini, F. (2007). Islam et développement économique. L'observatoire des religions, juillet 2007. Retrieved from http://www.observatoiredesreligions.fr.

Gardet, L. (1970). L'islam, Religion et Communauté, Paris : Descellée de Brouwer.

Guiso, L., Sapienza, P., \& Zingales, L. (2003). People's Opium Religion and Economic Activities. Journal of Monetary Economics, Elsevier, 50(1), 225-282, January. http://dx.doi:10.1016/s0304-3932(02)00202-7

Haenni, P. (2005). L’islam de marché. L'autre révolution conservatrice, éd. seuil, Paris, 2005.

Kuran, T. (1998). Islam et Sous-développement: un vieux puzzle revisité. Journal des Economistes et des Etudes Humaines, 8(1), mars.

Kuran, T. (2004). Islam and Mammon: The economic predicaments of Islamism. Princeton University Press

La Porta, R., De-silane, F. L., Shleifer, A., \& Vishny, R. W. (1997). Trust in Large Organizations. The American Economic Review, Papers and Proceedings, 87(2), 333-38.

McClelland, D. (1961). The achieving society, the free press, New York, 1961

Nafessi, M. (1998). Reframing Orientalism: Weber and Islam, Economy and society, 27(1), 97 - 118.

Noland, M. (2007). Religions, Islam et Croissance Economique : L'apport des analyses empiriques. Revue Française de Gestion, 33(171), 97-118. http://dx.doi/10.3161/rfg.171.97-118.

Pryor, F. L. (1985). The Islamic Economic System: A Review Article. Journal of Comparative Economics, 9(2).

Rodinson, M. (1966). Islam et Capitalisme, Paris, éd. Seuil (rééd. 1014, Paris, Demopolis, 228 pages)

Said, E. (1978). Orientalism. New York: pantheon Books, 1978

Sauvaget, .J. (1984). L’islam, que sais-je ?N³55, Paris, PUF 1984.

UNDP (2002). Arab Human Development Report: Creating Opportunities for Future Generations. Published for the United Nations Development Program. Retrieved from: http://www.hdr.undp.org.

Weber, M. (1968). Economy and Society, University of California Press. New York, 1968.

Note 1, - Sharia is a words and deeds of the Prophet or his close disciples Ijmaa is a consensus men of faith El Qyas is a personal interpretations of religious men according to the principles of Islam

Note 2, -The rejection of interest qualified illicit is justified by the fact that Islam considers the enrichment of an individual must result from a real activity and a supplied effort and not the operation of others.

Note 3, - All variables are taken from the Global Development Network Growth Database (GDNGD) from World Development Indicators (WDI), UNESCO Institute for Statistics (UIS) and Pew Research Center

Note 4, - A Muslim country is one that has more than 50\% of Muslims

Arab-Muslim countries are : Algeria, Bahrain, Egypt, Jordan, Mauritania, Morocco, Oman, Saudi Arabia, Sudan, Syria, Tunisia, United Emarate Saudi, Yemen

Non-Arab Muslim countries are : Albania, Indonesia, Iran, Pakistan, Turkey

Note $5,-\mathrm{F}(19,475)=1.16 ;(\mathrm{p}$-value $=0.2844)>5 \%$.

Note 6 , $-\mathrm{F}$ test that all $\mathrm{u} \_\mathrm{i}=0$ : $\quad \mathrm{F}(19,473)=1.16 ;$ Prob $>\mathrm{F}=0.2835$

Note 7, - H0: $\operatorname{sigma}(\mathrm{i})^{\wedge} 2=\operatorname{sigma}^{\wedge} 2$ for all I $; \operatorname{chi} 2(20)=1403.49 ;$ Prob $>\operatorname{chi} 2=0.0000$

- Breusch-Pagan LM test of independence: $\operatorname{chi} 2(190)=282.827 ; \operatorname{Pr}=0.0000$

Note 8 , - F test that all u_i $=0: F(19,473)=1.11$; Prob $>F=0.3325$

- H0: $\operatorname{sigma}(\mathrm{i})^{\wedge} 2=\operatorname{sigma}^{\wedge} 2$ for all i $: \operatorname{chi} 2(20)=1406.26 ;$ Prob $>\operatorname{chi} 2=0.0000$

- Breusch-Pagan LM test of independence: $\operatorname{chi} 2(190)=287.330, \operatorname{Pr}=0.0000$

Note 9 , the distinction between usury and interest, risk taking, anticipation, Opportunity Cost, etc.)

\section{(cc) $\mathrm{BY}$}

This work is licensed under a Creative Commons Attribution 3.0 License. 